\title{
Clinical significance of pretreatment Ca-P solubility product in 47 cats with chronic kidney disease
}

\author{
Ekrem Çağatay ÇOLAKOĞLU ${ }^{1, a, ~}{ }^{凶}$, Hadi ALİHOSSEİNí ${ }^{2, b}$, Ali Evren HAYDARDEDEOĞLU ${ }^{3, c}$ \\ ${ }^{1}$ Ankara University, Faculty of Veterinary Medicine, Department of Internal Medicine, Ankara; ${ }^{2}$ Veterinary Practitioner, Terapist \\ Veterinary Medical Center, İstanbul; ${ }^{3}$ Aksaray University, Faculty of Veterinary Medicine, Deparment of Internal Medicine, \\ Aksaray, Turkey. \\ aORCID: 0000-0003-2789-035X; bORCID: 0000-0001-8846-4827; ' ORCID: 0000-0002-8473-0072.
}

${ }^{凶}$ Corresponding author: colakoglu@ankara.edu.tr

Received date: 10.04.2019- Accepted date: 14.07.2019

\begin{abstract}
Chronic kidney disease (CKD) and mineral disorders are one of the most common reasons of cats. Alterations in mineral metabolism occur in early stage of CKD and increasing the severity in advanced stages. In Turkey, although some clinical studies on CKD in cats are available, no data concerning the clinical significance of pretreatment Ca-P solubility product is present. The purpose of the current study was to determine of Ca-P solubility product and its association with the life quality of cats with CKD. Staging system for classifying cats with chronic kidney disease was based on IRIS guideline. The following groups were occurred based on serum creatinine (SCr) and urine specific gravity < 1035: Stage 2= SCr $1.6-2.8 \mathrm{mg} / \mathrm{dl}$; Stage 3= SCr $2.9-5.0 \mathrm{mg} / \mathrm{dl}$; Stage $4=\mathrm{SCr}>5.0 \mathrm{mg} / \mathrm{dl}$. Solubility product (calcium x phosphorus) was also defined. Although calcium levels were within reference ranges in groups, Ca-P product were above $72 \mathrm{mg}^{2} / \mathrm{dl}^{2}$ in stage 3 and 4 cats. In conclusion, determination of pretreatment Ca-P solubility product in cats with different stages of CKD could be useful to modify and manage the life quality of cats with CKD.
\end{abstract}

Keywords: Calcium, cat, kidney disease, phosphorus.

\section{Kronik böbrek yetmezliği bulunan 47 kedide tedavi öncesi belirlenen Ca - P çarpımının klinik önemi}

Özet: Kronik böbrek yetmezliği (KBY) ve mineral metabolizması sorunları kedilerin yaygın klinik problemlerinden biridir. Mineral metabolizmasındaki değişimler KBY'nin erken aşamalarında başlamakta ve ileri aşamalarda ise şiddeti artmaktadır. Her ne kadar Ülkemizde KBY'li kedilerde yapılan bazı klinik çalışmalar mevcutsa da, bu çalışmaların hiç birinde tedavi öncesi belirlenen CaP çarpımının klinik önemine dair veri bulunmamaktadır. Çalışmanın amacı; KBY'li kedilerde Ca-P çarpımı ve yaşam kalitesiyle olan ilişkisini ortaya koymaktır. Çalışmada kronik böbrek yetmezliği olan kediler IRIS klasifikasyonuna göre sınıflandırıldı. Serum kreatinin ( $\mathrm{SCr}$ ) ve 1035'in altındaki idrar dansitesi baz alınarak böbrek yetmezliğinin şiddetine göre gruplar; 2 . aşama= $\mathrm{SCr} 1.6-2.8$ $\mathrm{mg} / \mathrm{dl} ; 3$. aşama $\mathrm{SCr}=2.9-5.0 \mathrm{mg} / \mathrm{dl}$ ve 4 . aşama $=\mathrm{SCr}>5.0 \mathrm{mg} / \mathrm{dl}$ olarak oluşturuldu. Kalsiyum fosfor çarpımı ayrıca tespit edildi. Her ne kadar gruplarda kalsiyum düzeyleri referans değerler arasındaysa da, kalsiyum fosfor çarpımı 3 ve 4 . aşama kedilerde 72 $\mathrm{mg}^{2} / \mathrm{dl}^{2}$ 'nin üzerinde belirlendi. Sonuç olarak KBY'nin çeşitli aşamalarındaki kedilerde Ca-P çarpımının tedavi öncesi belirlenmesi KBY'li kedilerde yaşam kalitesinin yönetilmesinde faydalı olabilir.

Anahtar sözcükler: Böbrek hastalı̆̆ı, fosfor, kalsiyum, kedi.

\section{Introduction}

Chronic kidney disease (CKD) and mineral disorders are a common clinical problem in aging cats. Structural or functional renal abnormalities develop in 1.6-20\% of all cats during their lifetime $(24,26)$. Alterations in mineral metabolism occur in early stage of CKD and increase the severity in advanced stage (26). Because of the progression of the disease, literature have focused the survival in cats with CKD $(7,17)$. In Turkey, although some clinical studies including heamatological and biochemical changes have been published in cats with CKD $(2,8)$, these studies have consisted of less case series and none of them had an explanation concerning the clinical significance of Ca-P solubility product. Human studies revealed the association between increased levels of serum phosphorus and increased mortality $(18,20)$. It has also been reported that human patients with a Ca-P product $>72 \mathrm{mg}^{2} / \mathrm{dl}^{2}$ have higher mortality risk compared to those with a Ca-P product between $42-52 \mathrm{mg}^{2} / \mathrm{dl}^{2}(5)$. The purpose of the current study was that although it is 
known the progression of CKD in cats, determination of Ca-P solubility product in different stages of CKD may be used to manage the life quality of cats with CKD.

\section{Material and Methods}

This study was a prospective clinical study in 69 clint-owned cats with the signs of polyuria, polydipsia, vomiting, anorexia, halitosis, lethargy, depression or small kidneys on palpation. Staging system for classifying cats with chronic kidney disease based on IRIS guidelines was used (16). The following groups were occurred based on serum creatinine ( $\mathrm{SCr}$ ) and urine specific gravity < 1035: Stage 2= SCr $1.6-2.8 \mathrm{mg} / \mathrm{dl}$; Stage 3= SCr $2.9-5.0$ $\mathrm{mg} / \mathrm{dl} ;$ Stage $4=\mathrm{SCr}>5.0 \mathrm{mg} / \mathrm{dl}$. Cats with proteinuria, high blood pressure and CKD Stage $1(\mathrm{SCr}<1.6 \mathrm{mg} / \mathrm{dl})$ were not included the IRIS staging. Cats with systemic disease such as diabetes mellitus, hyperthyroidism, neoplasia, postrenal obstruction and hepatic pathology were excluded from the study. Cats with feline infectious peritonitis, feline immunodeficiency virus or feline leukemia virus performed with speed tests were also excluded from the study. Cats were treated with appropriate medications. Clinical procedures including physical examination, complete blood count (Exigo ${ }^{\circledR} \mathrm{cbc}$ analyzer), serum profiles (Erba xl 600®), urinalysis (urine test strip) and abdominal ultrasonography (Shimadzu ${ }^{\circledR}$ Sdu 450) were performed in all cats. Solubility product (calcium $\mathrm{x}$ phosphorus- $\mathrm{mg}^{2} / \mathrm{dl}^{2}$ ) was also defined (4). Cats were fasted for at least 12 hour prior to blood sampling. Written owner consents were also obtained from the owners.

Statistical analysis: Data regarding characteristics of the cats were subjected to the Mean Procedure (SPSS, Version 16, Chicago, ILL). Clinical data were analyzed using cross-tabulation in chi-square test. Finally hematological parameters and serum biochemistry parameters were analyzed using the NPAR1WAY procedure. Differences by the stage were attained using Kruskal-Wallis test, employing chi square value and degree of freedom. Statistical significance was declared at $\mathrm{P}<0.05$.

\section{Results}

Data were collected from 69 clint-owned cats referred to hospital with the signs of kidney disease. Stage 1 cats (n:15) with renal insufficiency but not renal failure were excluded from the study. 7 cats with postrenal obstruction, hyperthyroidism, renal mass or hepatic pathology were not also included the study. Study were performed with 47 cats with chronic kidney disease. The mean age, weight, breed and sex distribution of cats in groups were shown in Table 1. Historical and physical examination findings in each group were also presented in Table 2. Table 3 and Table 4 revealed complete blood counts, serum profiles and urinalysis in groups.

Table 1. Characteristics of cats in groups.

\begin{tabular}{|c|c|c|c|c|}
\hline Staging* & Age (years) & Weight (kg) & Breeds (n) & $\operatorname{Sex}\left(\mathbf{n} \hat{O}^{\lambda}, \mathbf{n}_{+}\right)$ \\
\hline Stage 2, n:7 & $10.85 \pm 3.48$ & $3.42 \pm 0.51$ & $\begin{array}{l}\text { DSH (n:3), } \\
\text { Persian (n:2), } \\
\text { Siamese (n:2) }\end{array}$ & $4 \hat{O}, 3$ + \\
\hline Stage 3, n:11 & $11.59 \pm 4.87$ & $2.96 \pm 0.64$ & $\begin{array}{l}\text { DSH (n:8), } \\
\text { Siamese (n:2), } \\
\text { Van cat (n:1) }\end{array}$ & $3 \hat{O}^{\lambda}, 8$ + \\
\hline Stage 4, n:29 & $10.41 \pm 4.72$ & $3.09 \pm 0.80$ & $\begin{array}{l}\text { DSH (n:15), } \\
\text { Persian (n:4), } \\
\text { Siamese (n:4), } \\
\text { BSH (n:3), } \\
\text { Chinchilla (n:1), } \\
\text { Ankara cat (n:1) } \\
\text { Van cat (n:1) }\end{array}$ & $14 \hat{\jmath}, 15$ ㅇ \\
\hline $\mathrm{P}$ & $>0.05$ & $>0.05$ & & \\
\hline
\end{tabular}

DSH: Domestic short hair; BSH: British short hair; *Based on IRIS guidelines. 
Table 2. Historical and physical examination findings of cats in groups.

\begin{tabular}{llll}
\hline Historical exam findings & Stage 2, n: $\mathbf{( \% )}$ & Stage 3, n: 11 $(\boldsymbol{\%})$ & Stage 4, n: 29 $(\boldsymbol{\%})$ \\
\hline Polyuria/Polydipsia & $2(28)$ & $4(36)$ & $17(58)$ \\
Vomiting & $3(42)$ & $8(72)$ & $19(65)$ \\
Anorexia & $1(14)$ & $5(45)$ & $22(75)$ \\
Halitosis & - & $3(27)$ & $6(20)$ \\
Lethargy & $4(57)$ & $9(81)$ & $12(41)$ \\
Depression & - & $3(27)$ & $26(89)$ \\
\hline Physical exam findings & Stage 2, n: 7 (\%) & Stage 3, n: 11 (\%) & Stage 4, n: 29(\%) \\
\hline Dehydration & $3(42)$ & $9(81)$ & $26(89)$ \\
Pale mucous membranes & $1(14)$ & $2(18)$ & $8(27)$ \\
Murmur & $1(14)$ & $1(9)$ & $13(44)$ \\
Poor oral health & - & $3(27)$ & $18(62)$ \\
Poor hair health & - & $6(54)$ & $22(75)$ \\
Small kidneys on palpation* & $1(14 \%)$ & $5(45)$ & $24(82$ \\
(Uni- or Bilateral) & & & \\
\hline
\end{tabular}

*confirmed by abdominal ultrasonography

Table 3. Heamatology profiles in cats with chronic kidney disease.

\begin{tabular}{|c|c|c|c|c|c|c|c|}
\hline & $\begin{array}{c}\text { Stage 2, } \\
\text { n:7 } \\
(\text { Mean } \pm \text { SD })\end{array}$ & $\begin{array}{c}\text { Stage 2, } \\
\text { n:7 } \\
\text { (Median) }\end{array}$ & $\begin{array}{c}\text { Stage 3, } \\
\text { n:11 } \\
(\text { Mean } \pm \text { SD) }\end{array}$ & $\begin{array}{c}\text { Stage 3, } \\
\text { n:11 } \\
\text { (Median) }\end{array}$ & $\begin{array}{c}\text { Stage 4, } \\
\text { n:29 } \\
(\text { Mean } \pm \text { SD) }\end{array}$ & $\begin{array}{c}\text { Stage 4, } \\
\text { n:29 } \\
\text { (Median) }\end{array}$ & $X^{2} ; P$ \\
\hline WBC, $10^{9} / 1(5.5-19.5)$ & $8.40 \pm 4.45$ & 7,84 & $9.52 \pm 3.78$ & 7,25 & $12.58 \pm 9.65$ & 9,07 & $2.3 ; 0.3$ \\
\hline LYM, $10^{9}$ / 1 (1-7) & $1.84 \pm 0.40$ & 2,01 & $1.36 \pm 0.84$ & 1,54 & $1.94 \pm 1.55$ & 1,3 & $1.9 ; 0.45$ \\
\hline MONO, $10^{9} / 1(0.2-1)$ & $0.38 \pm 0.21$ & 0,38 & $1.14 \pm 1.64$ & 0,6 & $0.97 \pm 0.78$ & 0,66 & $4.9 ; 0.28$ \\
\hline NEUT, $10^{9} / 1$ (2.8-13) & $4.70 \pm 5.32$ & 1,96 & $6.80 \pm 4.14$ & 6,3 & $9.20 \pm 9.15$ & 6 & $4.3 ; 0.34$ \\
\hline EOS, $10^{9} / 1$ & $0.21 \pm 0.10$ & 0,28 & $0.23 \pm 0.14$ & 0,2 & $0.45 \pm 0.51$ & 0,29 & $4.4 ; 0.20$ \\
\hline LYM, \% & $35.65 \pm 17.6^{\mathrm{a}}$ & 42,9 & $18.95 \pm 15.6^{\mathrm{b}}$ & 11,4 & $18.9 \pm 15.5^{\mathrm{b}}$ & 14 & $1.9 ; 0.04$ \\
\hline MONO, \% & $5.90 \pm 2.24$ & 6,1 & $7.30 \pm 5.00$ & 6,1 & $7.62 \pm 4.18$ & 6,9 & $4.9 ; 0.62$ \\
\hline NEUT, \% & $54.02 \pm 21.3$ & 41,8 & $71.78 \pm 17.5$ & 78,7 & $63.83 \pm 22.79$ & 69,7 & $3.6 ; 0.24$ \\
\hline EOS, \% & $4.51 \pm 3.30$ & 6,9 & $2.18 \pm 1.21$ & 1,9 & $3.64 \pm 3.82$ & 3 & $1.6 ; 0.31$ \\
\hline RBC, $10^{12} / 1$ (5-11) & $6.61 \pm 1.50$ & 6,29 & $6.41 \pm 2.12$ & 5,89 & $5.87 \pm 1.92$ & 5,72 & $1.8 ; 0.55$ \\
\hline HGB, g/dl (8-15) & $10.34 \pm 3.20$ & 10 & $11.14 \pm 2.94$ & 10,6 & $9.83 \pm 2.56$ & 9 & $1.8 ; 0.40$ \\
\hline HCT, \% (25-45) & $27.88 \pm 6.65$ & 24,9 & $31.05 \pm 9.50$ & 32,23 & $26.52 \pm 9.75$ & 26,6 & $2.4 ; 0.39$ \\
\hline MCV, fl (39-50) & $42.28 \pm 3.88$ & 42,8 & $48.68 \pm 3.88$ & 48 & $46.68 \pm 6.13$ & 45 & $4.9 ; 0.08$ \\
\hline MCH, pg (12.5-17.5) & $15.47 \pm 2.75$ & 14 & $18.9 \pm 6.90$ & 17,4 & $17.57 \pm 4.99$ & 16,9 & $2.9 ; 0.40$ \\
\hline MCHC, g/dl (31-38.5) & $34.4 \pm 6.17$ & 32,2 & $34.02 \pm 4.09$ & 34,6 & $33.43 \pm 3.41$ & 33,1 & $0.07 ; 0.81$ \\
\hline RDW, \% (14-18.5) & $16.37 \pm 3.24$ & 15 & $15.42 \pm 2.94$ & 14,8 & $14.40 \pm 2.86$ & 13,7 & $3.67 ; 0.24$ \\
\hline PLT, $10^{9} / 1(200-500)$ & $313.2 \pm 242.8$ & 245 & $289.6 \pm 194.1$ & 254 & $370.53 \pm 225.5$ & 354 & $1.67 ; 0.54$ \\
\hline MPV, fl (8-12) & $11.68 \pm 1.53$ & 12 & $11.11 \pm 3.36$ & 10,5 & $11.07 \pm 3.49$ & 11,6 & $0.33 ; 0.90$ \\
\hline
\end{tabular}

$\overline{\mathrm{a}, \mathrm{b}}$ different letters are significantly different 
Table 4. Serum profiles in cats with chronic kidney disease.

\begin{tabular}{|c|c|c|c|c|c|c|c|}
\hline & $\begin{array}{c}\text { Stage } 2 \\
\text { n:7 } \\
(\text { Mean } \pm \text { SD }) \\
\end{array}$ & $\begin{array}{c}\text { Stage 2, } \\
\text { n:7 } \\
\text { (Median) }\end{array}$ & $\begin{array}{c}\text { Stage 3, } \\
\text { n:11 } \\
(\text { Mean } \pm \text { SD) } \\
\end{array}$ & $\begin{array}{c}\text { Stage 3, } \\
\text { n:11 } \\
\text { (Median) }\end{array}$ & $\begin{array}{c}\text { Stage 4, } \\
\text { n:29 } \\
(\text { Mean } \pm \text { SD) } \\
\end{array}$ & $\begin{array}{c}\text { Stage 4, } \\
\text { n:29 } \\
\text { (Median) }\end{array}$ & $X^{2} ; P$ \\
\hline Urea, mg/dl (15-64.2) & $93.3 \pm 42.4$ & 84,8 & $126.05 \pm 59.46$ & 116,6 & $162.69 \pm 100.2$ & 130 & $3.54 ; 0.13$ \\
\hline Creatinin, mg/dl (0.8-1.8) & $2.30 \pm 0.39^{\mathrm{a}}$ & 2,4 & $3.96 \pm 0.59^{\mathrm{a}}$ & 3,93 & $7.90 \pm 2.42^{\mathrm{b}}$ & 7,7 & $34.4 ;<0.0001$ \\
\hline T. Protein, g/dl (5.4-7.8) & $6.65 \pm 1.57$ & 7,5 & $7.01 \pm 0.90$ & 6,71 & $7.50 \pm 1.34$ & 7,4 & $1.23 ; 0.23$ \\
\hline Glucose, mg/dl (70-110) & $97.7 \pm 15.1$ & 95 & $120.46 \pm 44.11$ & 97 & $126.56 \pm 33.23$ & 124 & $5.3 ; 0.14$ \\
\hline Albumin, g/dl (3.5-4.5) & $2.58 \pm 1.22$ & 2,5 & $3.26 \pm 0.71$ & 3,1 & $2.92 \pm 0.40$ & 2,9 & $2.6 ; 0.10$ \\
\hline T. Bilirubin, mg/dl (0.1-0.2) & $0.25 \pm 0.15$ & 0,24 & $0.26 \pm 0.16$ & 0,2 & $0.35 \pm 0.38$ & 0,21 & $0.7 ; 0.65$ \\
\hline ALP, IU/1 (25-93) & $29.6 \pm 11.4$ & 30 & $59.92 \pm 70.9$ & 36,9 & $36.17 \pm 26.43$ & 28 & $1.77 ; 0.19$ \\
\hline AST, IU/1 (26-43) & $18.3 \pm 7.82^{\mathrm{a}}$ & 15 & $43.55 \pm 36.40^{\mathrm{b}}$ & 34 & $56.18 \pm 35.13^{b}$ & 59 & $9.92 ; 0.03$ \\
\hline ALT, IU/l (6-83) & $36.2 \pm 31.7$ & 24 & $65.02 \pm 59.17$ & 25 & $64.74 \pm 44.70$ & 59 & $2.75 ; 0.33$ \\
\hline GGT, IU/1 (6-28) & $2.00 \pm 1.82$ & 1 & $5.41 \pm 8.30$ & 2,9 & $2.68 \pm 4.17$ & 1 & $1.97 ; 0.27$ \\
\hline Ca, mg/dl (7.5-10.8) & $9.80 \pm 1.11$ & 9,5 & $9.59 \pm 0.95$ & 9,6 & $9.77 \pm 1.07$ & 9,7 & $0.08 ; 0.86$ \\
\hline I. Phosphorus, mg/dl & $5.34 \pm 2.27^{\mathrm{a}}$ & 4,3 & $7.66 \pm 3.61^{\mathrm{a}}$ & 5,6 & $13.05 \pm 3.04^{\mathrm{b}}$ & 13,1 & $21.5 ;<0.0001$ \\
\hline Na, mmol/l (146-159) & $151.5 \pm 7.5$ & 155 & $148.45 \pm 5.98$ & 149 & $147.117 \pm 26.04$ & 151 & $2.29 ; 0.88$ \\
\hline $\mathbf{K}, \mathrm{mmol} / \mathrm{l}(3.8-5.3)$ & $3.91 \pm 0.59$ & 3,9 & $4.07 \pm 0.76$ & 3,9 & $4.53 \pm 1.10$ & 4,3 & $3.74 ; 0.20$ \\
\hline Ca x P Product, $\mathrm{mg}^{2} / \mathrm{dl}^{2}$ & $52.4 \pm 23.2^{\mathrm{a}}$ & 41,65 & $73.12 \pm 33.95^{\mathrm{a}}$ & 58,3 & $127.427 \pm 31,52^{\mathrm{b}}$ & 136,4 & $22.21 ;<0.0001$ \\
\hline Urine Specific Gravity & $1032.5 \pm 6.3$ & 1025 & $1030.8 \pm 6.4$ & 1024 & $1025.8 \pm 5.3$ & 1021 & $7.5 ; 0.04$ \\
\hline Urine $\mathbf{P h}$ & $6.25 \pm 0.41$ & 6 & $6.32 \pm 0.52$ & 6.1 & $6.81 \pm 0.43$ & 6.5 & $8.8 ; 0.04$ \\
\hline
\end{tabular}

a,b different letters are significantly different

\section{Discussion and Conclusion}

$\mathrm{CKD}$ is the most common metabolic disease of aging cats. Age-related increase in the prevalence of CKD in cats has been reported (23). Renal disorders in cats above 13 years of age have been identified as the most common cause of death (14). Mortality in cats with CKD has defined as $4 \%$ between 1 to 5 years of age and $17 \%$ in cats dying at $\geq 11$ years of age (19). Although survival was not the aim of this study and younger cats included in each group, the mean age of all cats in groups were about 11 year old.

Severity of the CKD associated complications such as hyperphosphatemia, secondary renal hyperparathyroidism, hypokalemia, anemia, proteinuria, hypertension and uremia as well as the process of treatment and prognosis vary in advancing IRIS stage $(7,16)$. In $30 \%$ to $65 \%$ of cats with $\mathrm{CKD}$, anemia could develop attributable to decreased erythropoietin production (10). In a study previously defined, no significant correlations were found between anemia and survival in cats with CKD (15). Although anemia is a common finding in cats with end stage CKD (11), in this study it was not a remarkable finding. Dehydration was thought as the possible reason of masking the anemia in cats with CKD.

Some studies performed in cats with CKD based on elevated blood creatinine concentrations to diagnose the kidney disease in cats with or without clinical signs (4, 17). IRIS guidelines also confirmed creatinine measurements for staging the renal failure (16). Creatinine levels obtained from this study were statistically significant in each IRIS stages as consistent with the reports previously described.

Hyperphosphatemia is a clinicopathologic marker of renal fibrosis, mortality and progression of CKD in cats (22). Phosphorus level in early stages of CKD is kept within reference ranges by parathyroid hormone (PTH). However, phosphorus level can no longer maintain in cats with IRIS stage 2, 3 and 4 because of decreasing the glomerular filtration rate $(1,13)$. Data obtained from the current study supported this finding. Although we do not know the PTH levels in cats with different IRIS stages of CKD, inorganic phosphorus levels in IRIS stages gradually increased in this study.

CKD is a concurrent disease in cats with hypercalcemia (9). Several mechanism including decreased glomerular filtration and bone storage of calcium and, increased tubular reabsorption have supported the hypercalcemia risk (25). Whether CKD is a risk factor for hypercalcemia is still unclear (9). In some studies $11.5-21 \%$ of cats with CKD had concurrent hypercalcemia $(3,12,27)$. In this study presented here mean calcium concentrations in groups were within reference ranges and no significant differences were found among groups.

In a study obtained from 50 cats, higher phosphorus level has been associated with a higher risk of death within 1 month. In the same study, higher urea and serum creatinine concentrations were also related to increased risk of death (21). In another study (7) $11.8 \%$ increase in the risk of death was defined for each 1 unit increase in 
phosphorus level. In Turkey, although some studies including clinical, heamatological and biochemical changes have been published in cats with $\operatorname{CKD}(2,8)$, none of them had an explanation concerning the clinical significance of Ca-P solubility product. Point out the determination of $\mathrm{Ca}-\mathrm{P}$ solubility product in different stages of CKD to modify the prognosis and manage the life quality of cats with CKD is the main purpose of the current study. In a human study (5), patients with a Ca-P solubility product above $72 \mathrm{mg}^{2} / \mathrm{dl}^{2}$ had a $34 \%$ higher risk of death compared with those with a Ca-P product between $42-52 \mathrm{mg}^{2} / \mathrm{dl}^{2}$. It has been also reported that cats with soft tissue calcifications had elevated levels of Ca-P product (above $70 \mathrm{mg}^{2} / \mathrm{dl}^{2}$ ) with or without hypercalcemia $(4,6)$. In the current study although calcium levels were within reference ranges in each group, Ca-P product were above $72 \mathrm{mg}^{2} / \mathrm{dl}^{2}$ in stage 3 and 4 cats as consistent with the reports previously described $(4,6)$.

In conclusion, determination of pretreatment $\mathrm{Ca}-\mathrm{P}$ solubility product in cats with different stages of CKD could be useful to modify and manage the life quality of cats with CKD.

\section{Acknowledgements}

Special thanks to Prof. Dr. Armağan Hayırlı for statistical analyses of the study.

\section{Conflict of Interest}

The authors declared that there is no conflict of interest.

\section{References}

1. Albaaj F, Hutchinson AJ (2003): Hyperphosphatemia in renal failure, causes, consequences and current management. Drugs, 63, 577-96.

2. Altıntaş A, Üren N, Pekcan M, et al (2006): Kronik böbrek yetmezliği belirtileri gösteren kedilerde biyokimyasal ve hematolojik değişiklikler. Ankara Univ Vet Fak Derg, 53, 97-102.

3. Barber PJ, Elliott J (1995): Feline chronic renal failure: calcium homeostasis in 80 cases diagnosed between 1992 and 1995. J Small Anim Pract, 39, 108-11.

4. Bertazzolo W, Toscani L, Calcaterra S, et al (2003): Clinicopathological findings in five cats with paw calcification. JMFS, 5, 11-17.

5. Block GA, Hulbert-Shearon TE, Levin NW, et al (1998): Association of serum phosphorous and calcium x phosphate product with mortality risk in chronic hemodialysis patients: a national study. Am J Kidney Dis, 31, 607-17.

6. Bohmer E, Hanichen T, Lohss E (1991): Cutaneous calcinosis of the foodpads in a cat. Tierarztliche Praxis, 19, 88-95.

7. Boyd LM, Langston C, Thompson K, et al (2008): Survival in cats with naturally occurring chronic kidney disease (2000 -2002). J Vet Intern Med, 22, 1111-1117.

8. Börkü MK, Durgut R, Kurtdede A, et al (2000): Kronik böbrek yetmezligi belirtileri gösteren kedi ve köpeklerde klinik, laboratuvar ve patolojik bulgular. Ankara Univ Vet Fak Derg, 47, 288-289.
9. Broek DHN, Chang YM, Elliott J, et al (2017): Chronic kidney disease in cats and the risk of total hypercalcemia. $\mathrm{J}$ Vet Intern Med, 31, 465-475.

10. Chalhoub S, Langston C, Eatroff A (2011): Anemia of renal disease: what it is, what to do and what's new. J Feline Med Surg, 13, 629-640.

11. Cooks M, Lothrorp CD (1994): Serum erythropoietin concentrations measured by radioimmunoassay in normal, polycythernic, and anemic dogs and cats. J Vet Intern Med, 8, 18-25.

12. Dibartola SP, Rutgers HC, Zack PM, et al (1987): Clinicopathologic findings associated with chronic renal disease in cats: 74 cases (1973-1984). J Am Vet Med Assoc, 190, 1196-1202.

13. Dibartola SP, Willard MD (2006): Disorders of phosphorous: hypophosphatemia and hyperphosphatemia. 195-209. In: SP Dibartola (Ed), Fluid, Electrolyte, and Acid-Base Disorders in Small Animal Practice. Elsevier, Missouri.

14. Egenvall A, Nodtvedt A, Haggstrom J, et al (2009): Mortality of life-insured Swedish cats during 1999-2006: age, breed, sex, and diagnosis. J Vet Intern Med, 23, 11751183.

15. Elliot J, Rawlings JM, Markwell PJ, et al (2000): Survival of cats with naturally occurring chronic renal failure. Effect of dietary management. J Small Anim Pract, 41, 235-242.

16. Elliott J, Watson A (2014): Chronic kidney disease: International Renal Interest Society staging and management. 857-863. In: J Bonagura, D Twedt (Ed). Current Veterinary Therapy, Saunders-Elsevier, Louis.

17. Elliotta J, Barber PJ (1998): Feline chronic renal failure: clinical findings in 80 cases diagnosed between 1992 and 1995. J Small Anim Pract, 39, 78-85.

18. Ganesh SK, Stack AG, Levin NW, et al (2001): Association of elevated serum $\mathrm{PO}_{4}, \mathrm{Ca} \times \mathrm{PO}_{4}$ product, and para - thyroid hormone with cardiac mortality risk in chronic hemodialysis patients. J Am Soc Nephrol, 12, 2131-138.

19. Hamilton JB, Hamilton RS, Mestler GE (1969): Duration of life and causes of death in domestic cats: influence of sex, gonadectomy, and inbreeding. J Gerontol, 24, 427-437.

20. Kestenbaum B, Sampson JN, Rudser KD, et al (2005): Serum phosphate levels and mortality risk among people with chronic kidney disease. Am Soc Nephrol, 16, 520-528.

21. Kuwahara Y, Ohba Y, Kitoh K, et al (2006): Association of laboratory data and death within one month in cats with chronic renal failure. J Small Anim Pract, 47, 446-450.

22. Lawson J, Elliott J, Wheeler-Jones C, et al (2015): Renal fibrosis in feline chronic kidney disease: known mediators and mechanisms of injury. Vet J, 203, 18-26.

23. Lulich P, Osborne C, O'brien T D, et al (1992): Feline renal failure: questions, answers. questions. Compendium, 14, 127-152.

24. Lund EM, Armstrong PJ, Kirk CA, et al (1999): Health status and population characteristics of dogs and cats examined at private veterinary practices in the United States. J Am Vet Med Assoc, 214, 1336-1341.

25. Peacock M (2010): Calcium metabolism in health and disease. Clin J Am Soc Nephrol, 5, 23-30.

26. Polzin DJ (2011): Chronic kidney disease in small animals. Vet Clin North Am: Small Anim Pract, 41, 15-30.

27. Schenck PA, Chew DJ (2008): Calcium: total or ionized? Vet Clin North Am: Small Anim Pract, 38, 497-502. 